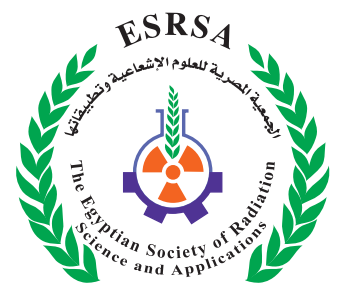

J. Nucl. Tech. Appl. Sci., Vol. 7, PP. 151 : 159 (2019)

\title{
Toxicological and Repellent Effects of Lantana camara (Verbenaceae) and Eucalyptus citriodora (Myrtaceae) Extracts against Rift Valley Fever Vector, Culex antennatus (Becker) (Diptera: Culicidae)
}

Shehata, A.Z.I.; Hammad, K.M. and Abdel-Samad, M.R.K.

\begin{tabular}{l}
\hline Received: $21 / 02 / 2019$ \\
Accepted: $07 / 04 / 2019$
\end{tabular}

E.mail: ahmed.ibrahem84@azhar.edu.eg

\section{KEYWORDS}

Larvicidal, Repellent, Culex antennatus, Lantana camara, Eucalyptus citriodora.

\section{ABSTRACT}

Culex antennatus (Becker) play an important role in transmission of Rift Valley Fever virus in the Nile Delta of Egypt. The present study aimed to evaluate the larvicidal activity of ethanol $70 \%$ and hexane extracts from Lantana camara and Eucalyptus citriodora leaves against the C. antennatus third larval instar. In addition, the repellent activity of the tested extracts against $C$. antennatus starved females was examined. The obtained results revealed that, hexane extract of tested plants was more effective against $3^{\text {rd }}$ instar larvae of $C$. antennatus than ethanolic extract. The $\mathrm{LC}_{50}$ values of hexane extracts recorded 84.4, 158.6; 71.3, 129.1 and 64.0, $113.3 \mathrm{ppm}$ after 24, 48 and 72 hours post treatment for $L$. camara and E. citriodora, respectively. Also, the tested ethanolic and hexane extracts of $L$. camara and E. citriodora (leaves) evoked a variable degree of repellency against $C$. antennatus starved females. The ethanolic extract exhibited 86.2, 68.8, 57.9 and 74.1, 59.0, 47.3\% protection for $L$. camara and E. citriodora at 3.33, 1.67 and $0.83 \mathrm{mg} / \mathrm{cm}^{2}$. Potent repellency $(92.5 \%)$ achieved by L. camara hexane extract at $1.67 \mathrm{mg} / \mathrm{cm}^{2}$ through the $3 \mathrm{~h}$ post treatment, Also, E. citriodora (leaves) hexane extract showed $88.1,77.8$ and $53.7 \%$ repellency at $3.33,1.67$ and $0.83 \mathrm{mg} / \mathrm{cm}^{2}$.

1. Department of Zoology, Faculty of Science, Al-Azhar University, Nasr City, Cairo 11651, Egypt 


\section{INTRODUCTION}

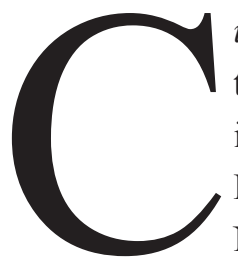

ulex antennatus (Becker) is one of the most important vectors in Egypt; it is the main vector of Rift Valley Fever virus during an outbreak in the Nile Delta of Egypt. Immature stages of mosquitoes are attractive targets for pesticides because they breed in water and thus are easy to deal with them in this habitat (Johnson and Singh, 2017). Mosquito eggs, larvae and pupae are usually targeted using conventional chemical insecticides, including organochlorides, pyrethroids mainly the deltamethrin and organophosphates such as malathion and fenthion as last resort for vector control (Ravaomanarivo et al., 2014). The usages of these synthetic compounds are not only environmentally polluting but also have concomitant hazardous effects to non-target organisms and to human health (Raharimalala et al., 2012). In addition, the extensive use of synthetic insecticides (Yang et al., 2002), resistance to the widely used chemical insecticides and the appearance of the secondary pests have stimulated many institutions and researchers to be engaged with the search for some environmentally safe control agents in order to avoid the disadvantages and hazards of the synthetic insecticides. A great part of efforts have been achieved for the investigation and re-examination of plant sources to obtain natural compounds which may act as growth regulation, fecundity suppression, male sterility, loss of flying ability, immune depression and enzyme inhibition repellent or anti-feedant characteristics ( $\mathbf{S u}$ and Mulla, 1998; Thomas and Callaghan, 1999). These compounds are called Plant-natural products, which are considered as defensive means against the animals and insects which attack the plants (Perveen et al., 2008). Thus, the aim of the present study was to evaluate the larvicidal and repellent activities of ethanol 70\% and hexane extracts from Lantana camara and Eucalyptus citriodora leaves against the Rift Valley Fever Vector, C. antennatus.

\section{MATERIALS AND METHODS}

\section{Culex antennatus culture}

The Rift Valley fever vector, Culex antennatus larvae were collected from Shubramunt, Giza, Egypt and maintained continuously for several generations in Medical Entomology Insectary, Animal house using the standard procedures described by Adham et al. (2003).

\section{Plant collection and preparation of crude extract}

Lantana camara and Eucalyptus citriodora collected during April 2017 from Sadat City, Egypt away from sun rays were left to dry at room temperature $\left(25-30^{\circ} \mathrm{C}\right)$ for 5 to 10 days and pulverized to powder separately in a hammer mill. The extraction was performed using ethanol $70 \%$ and hexane. One hundred grams of powder from L. camara and $E$. citriodora (leaves) for each solvent separately were extracted and filtered five times using $300 \mathrm{ml}$ of ethanol $70 \%$ and hexane at room temperature. After 24 h., the supernatants were decanted, filtrated through whatman filter paper (No. 5) and dried in a rotary evaporator. The dry extracts were weighed and kept at $-4^{\circ} \mathrm{C}$ till using for experiments.

\section{Larvicidal activity}

The tested material of the ethanolic extracts was dissolved in $0.1 \mathrm{ml}$ of ethanol $70 \%$, while the tested material of hexane extract was dissolved in 2 drop of Tween ${ }_{80}$. Different concentrations of each extract were performed in $250 \mathrm{ml}$. of dechlorinated tap water contained in $300 \mathrm{ml}$ plastic cups. Then, third instar larvae (25 larvae) were put immediately into plastic cups contained different concentrations of extracts. Three replicates were usually used for each tested concentration. Control larvae received only $0.1 \mathrm{ml}$ of ethanol $70 \%$ or 2 drop of Tween $_{80}$ in $250 \mathrm{ml}$ water (El-Sheikh et al., 2012).

Mortalities were recorded every 24 hours and indicated by a failure to respond to mechanical stimulation (Williams et al., 1986). However, acute 
mortalities are mortalities in the first 12 hours and chronic mortalities are mortalities calculated after 72 hours of treatment. Mortality was calculated using Abbott's equation formula.

\section{Repellent activity}

Standard cages $(20 \times 20 \times 20 \mathrm{~cm})$ were used to test the repellent activity of ethanolic and hexane extracts from L. camara and E. citriodora (leaves). Different weights from each extract were dissolved in $2 \mathrm{ml}$ (ethanolic and hexane with a drop of Tween $_{80}$ separately) in glass $4 \times 4 \mathrm{~cm}$ to prepare different concentrations. The concentration was directly applied onto $5 \times 6 \mathrm{~cm}$ of ventral surface of pigeon after feathers removal from the abdomen to evaluate the repellency against $C$. antennatus compared with commercial repellent DEET (N. N. diethyl-meta- toulamide) (Johnson Wax Egypt) as a positive control. After 10 minutes, the treated pigeons were placed in the cages $(20 \times 20 \times 20 \mathrm{~cm})$ containing $C$. antennatus starved females (5-7d-old) for three hours. Control tests were carried out alongside with the treatments using ethanol or water. After treatments, the number of fed and unfed females were counted and calculated according to Abbott (1925): Repellency \% $=[\% \mathrm{~A}-\% \mathrm{~B} /$ $100-\% \mathrm{~B}] \times 100$ (where: $\mathrm{A}=$ percent of unfed females in treatment and $\mathrm{B}=$ percent of unfed females in control).

\section{Statistical analysis}

Statistical analysis of the data was carried out according to the method of Lentner et al. (1982). $\mathrm{LC}_{50}$ was calculated using multiple linear regression (Finney, 1971).

\section{RESULTS}

As shown from the results, the highest larval mortality recorded after 24 hours by ethanolic extract from leaves of L. camara and E. citriodora was 69.2 and $62.8 \%$ at the highest concentrations (500 and $800 \mathrm{ppm}$ ), while the lowest mortality was 24.0 and $18.8 \%$ at the lowest concentrations (25 and 50 ppm) (Table 1). However, the concentrations 500, 400, 300, 200, 100, 50 and $25 \mathrm{ppm}$ from L. cama$r a$ ethanolic extract induced 86.8, 70.8, 60.0, 49.2, $42.8,33.2,25.2$ and 100.0, 92.0, 68.0, 53.2, 50.8, 40.0, 28.3\% larval mortality, respectively, after 48 and 72 hours (Table 1). On the other hand, at 800, $700,600,500,400,300,200,100$ and $50 \mathrm{ppm}$ from E. citriodora ethanolic extract induced larval mortality percent equal to $89.2,84.0,61.2,58.8,42.8$, $37.2,33.2,29.2,22.8$ and 100.0, 90.8, 76.0, 65.2, $52.0,46.8,37.2,34.8,25.2 \%$ after 48 and 72 hours, respectively, compared with $0.0 \%$ larval mortality in the control group. L. camara and E. citriodora (leaves) ethanolic extract recorded a variable acute mortality percent depending on the concentration of the extract, as it increased with the concentration of two extracts increasing. Ethanolic of L. camara (leaves) recorded 18.8, 22.8, 24.0, 30.8, 34.8, 37.2 and 46.8 acute mortality percentages at $25,50,100$, 200, 300, 400 and 500 ppm, respectively (Table 1). Meanwhile, acute mortality percent recorded by ethanolic of E. citriodora (leaves) were 41.2, 34.8, $32.0,26.8,25.2,24.0,22.8,21.2$ and $17.2 \%$ at 800 , $700,500,400,200,100$ and $50 \mathrm{ppm}$, respectively (Table 1). The survival potential recorded 0.0, 9.2, $24.0,34.8,48.0,53.2,62.8,65.2$ and $74.8 \%$ at 800 , $700,600,500,400,300,200,100$ and $50 \mathrm{ppm}$ by E. citriodora (leaves) ethanolic extract and 0.0, 8.0, $32.0,46.8,49.2,60.0$ and $72.0 \%$ at $500,400,300$, $200,100,50$ and 25 ppm by ethanolic of L. camara (leaves), respectively, compared with $100.0 \%$ survival potential percent in the untreated groups.

After 24 hours both hexane extracts from leaves of $L$. camara and E. citriodora exhibited larval mortality percent equal to $92.0,77.2,64.0,62.8,50.8$, $32.0,25.2,16.0,14.8$ and $88.0,74.8,57.2,42.8$, $33.2,26.8,21.2,10.8 \%$ at $160,140,120,100,80$, $60,40,20,10$ and $300,250,200,150,100,50,25$, $12.5 \mathrm{ppm}$, respectively (Table 1 ). In addition, after 72 hours post treatment the larval mortality were $100.0,90.8,82.8,76.0,61.2,50.8,33.2,22.8,18.8$ and $100.0,86.8,70.8,54.8,48.0,38.8,29.2,18.8 \%$ 
at $160,140,120,100,80,60,40,20,10$ and 300, for hexane extracts of L. camara and E. citriodora 250, 200, 150, 100, 50, 25, $12.5 \mathrm{ppm}$, respectively, (leaves).

Table (1) : Toxic effect of L. camara leaves ethanolic extract on $3 r d$ the instar larvae of $C$. antennatus.

\begin{tabular}{|c|c|c|c|c|c|c|c|c|}
\hline \multirow{2}{*}{ Plant Sp. } & \multirow{2}{*}{ Extract } & \multirow{2}{*}{$\begin{array}{l}\text { Conc. } \\
\text { (ppm) }\end{array}$} & \multicolumn{3}{|c|}{$\begin{array}{l}\text { Larval Mortality } \\
(\%)\end{array}$} & \multirow{2}{*}{$\begin{array}{c}\text { Acute } \\
\text { Mortality } \\
\text { (\%) }\end{array}$} & \multirow{2}{*}{$\begin{array}{c}\text { Chronic } \\
\text { mortality } \\
(\%)\end{array}$} & \multirow{2}{*}{$\begin{array}{c}\text { Survival } \\
\text { potential } \\
(\%)\end{array}$} \\
\hline & & & $24 h$. & $48 \mathrm{~h}$. & $72 \mathrm{~h}$. & & & \\
\hline \multirow{18}{*}{ L. camara } & \multirow{8}{*}{$\begin{array}{c}\text { Ethanol } \\
70 \%\end{array}$} & 500 & 69.2 & 86.8 & 100.0 & 46.8 & 100.0 & 0.0 \\
\hline & & 400 & 52.0 & 70.8 & 92.0 & 37.2 & 92.0 & 8.0 \\
\hline & & 300 & 45.2 & 60.0 & 68.0 & 34.8 & 68.0 & 32.0 \\
\hline & & 200 & 42.8 & 49.2 & 53.2 & 30.8 & 53.2 & 46.8 \\
\hline & & 100 & 34.8 & 42.8 & 50.8 & 24.0 & 50.8 & 49.2 \\
\hline & & 50 & 28.0 & 33.2 & 40.0 & 22.8 & 40.0 & 60.0 \\
\hline & & 25 & 24.0 & 25.2 & 28.0 & 18.8 & 28.0 & 72.0 \\
\hline & & Control & 0.0 & 0.0 & 0.0 & 0.0 & 0.0 & 100.0 \\
\hline & \multirow{10}{*}{ Hexane } & 160 & 92.0 & 100.0 & 100.0 & 58.8 & 100.0 & 0.0 \\
\hline & & 140 & 77.2 & 86.8 & 90.8 & 42.8 & 90.8 & 9.2 \\
\hline & & 120 & 64.0 & 74.8 & 82.8 & 40.0 & 82.8 & 17.2 \\
\hline & & 100 & 62.8 & 69.2 & 76.0 & 37.2 & 76.0 & 24.0 \\
\hline & & 80 & 50.8 & 56.0 & 61.2 & 32.0 & 61.2 & 38.8 \\
\hline & & 60 & 32.0 & 42.8 & 50.8 & 25.5 & 50.8 & 49.2 \\
\hline & & 40 & 25.2 & 30.8 & 33.2 & 18.8 & 33.2 & 66.8 \\
\hline & & 20 & 16.0 & 21.2 & 22.8 & 13.2 & 22.8 & 77.2 \\
\hline & & 10 & 14.8 & 17.2 & 18.8 & 9.2 & 18.8 & 81.2 \\
\hline & & Control & 0.0 & 0.0 & 0.0 & 0.0 & 0.0 & 100.0 \\
\hline \multirow{19}{*}{$\begin{array}{c}E . \\
\text { citriodora }\end{array}$} & \multirow{10}{*}{$\begin{array}{c}\text { Ethanol } \\
70 \%\end{array}$} & 800 & 62.8 & 89.2 & 100.0 & 41.2 & 100.0 & 0.0 \\
\hline & & 700 & 49.2 & 84.0 & 90.8 & 34.8 & 90.8 & 9.2 \\
\hline & & 600 & 42.8 & 61.2 & 76.0 & 32.0 & 76.0 & 24.0 \\
\hline & & 500 & 36.0 & 58.8 & 65.2 & 26.8 & 65.2 & 34.8 \\
\hline & & 400 & 33.2 & 42.8 & 52.0 & 25.2 & 52.0 & 48.0 \\
\hline & & 300 & 30.8 & 37.2 & 46.8 & 24.0 & 46.8 & 53.2 \\
\hline & & 200 & 25.2 & 33.2 & 37.2 & 22.8 & 37.2 & 62.8 \\
\hline & & 100 & 24.0 & 29.2 & 34.8 & 21.2 & 34.8 & 65.2 \\
\hline & & 50 & 18.8 & 22.8 & 25.2 & 17.2 & 25.2 & 74.8 \\
\hline & & Control & 0.0 & 0.0 & 0.0 & 0.0 & 0.0 & 100.0 \\
\hline & \multirow{9}{*}{ Hexane } & 300 & 88.0 & 100.0 & 100.0 & 45.2 & 100.0 & 0.0 \\
\hline & & 250 & 74.8 & 81.2 & 86.8 & 42.8 & 86.8 & 13.2 \\
\hline & & 200 & 57.2 & 65.2 & 70.8 & 33.2 & 70.8 & 29.2 \\
\hline & & 150 & 42.8 & 48.0 & 54.8 & 29.2 & 54.8 & 45.2 \\
\hline & & 100 & 33.2 & 45.2 & 48.0 & 22.8 & 48.0 & 52.0 \\
\hline & & 50 & 26.8 & 34.8 & 38.8 & 18.8 & 38.8 & 61.2 \\
\hline & & 25 & 21.2 & 26.8 & 29.2 & 16.0 & 29.2 & 70.8 \\
\hline & & 12.5 & 10.8 & 13.2 & 18.8 & 9.2 & 18.8 & 81.2 \\
\hline & & Control & 0.0 & 0.0 & 0.0 & 0.0 & 0.0 & 100.0 \\
\hline
\end{tabular}


Acute mortality percent attained by L. camara and E. citriodora (leaves) hexane extracts recorded $58.8,42.8,40.0,37.2,32.0,25.5,18.8,13.2,9.2$ and $45.2,42.8,33.2,29.2,22.8,18.8,16.0,9.2 \%$ at 160 , $140,120,100,80,60,40,20,10$ and $300,250,200$,
$150,100,500,25,12.5$ ppm, respectively. From $\mathrm{LC}_{50}$ values it is obvious that, hexane extract of $L$. camara and E. citriodora (leaves) was more effective than ethanolic extract (Table 2).

Table (2): Lethal concentrations of L. camara and E. citriodora leaves extracts against $C$. antennatus third .

\begin{tabular}{|c|c|c|c|c|c|c|c|c|c|}
\hline \multirow[b]{2}{*}{ Extract } & \multirow{2}{*}{$\begin{array}{l}\text { Time } \\
\text { (hours) }\end{array}$} & \multicolumn{2}{|c|}{$\mathrm{LC}_{50}(\mathrm{ppm})$} & \multicolumn{2}{|c|}{$\mathbf{L C}_{95}(\mathrm{ppm})$} & \multicolumn{2}{|c|}{ Slope (b) } & \multicolumn{2}{|c|}{$\mathbf{R}^{2}$} \\
\hline & & $\begin{array}{c}L . \\
\text { camara }\end{array}$ & $\begin{array}{c}E . \\
\text { citriodora }\end{array}$ & $\begin{array}{c}L . \\
\text { camara }\end{array}$ & $\begin{array}{c}E . \\
\text { citriodora }\end{array}$ & $\begin{array}{c}L . \\
\text { camara }\end{array}$ & $\begin{array}{c}E . \\
\text { citriodora }\end{array}$ & $\begin{array}{c}L . \\
\text { camara }\end{array}$ & $\begin{array}{c}E . \\
\text { citriodora }\end{array}$ \\
\hline \multirow{3}{*}{$\begin{array}{c}\text { Ethanol } \\
70 \%\end{array}$} & 24 & 318.5 & 686.1 & 864.0 & 1579.0 & 0.0825 & 0.0504 & 0.9517 & 0.9342 \\
\hline & 48 & 203.1 & 394.8 & 586.4 & 907.4 & 0.1174 & 0.0878 & 0.9814 & 0.9505 \\
\hline & 72 & 143.1 & 316.4 & 457.8 & 779.3 & 0.143 & 0.0972 & 0.9625 & 0.980 \\
\hline \multirow{3}{*}{ Hexane } & 24 & 84.4 & 158.6 & 171.0 & 339.0 & 0.5194 & 0.2493 & 0.9829 & 0.9814 \\
\hline & 48 & 71.3 & 129.1 & 152.5 & 299.1 & 0.5543 & 0.2648 & 0.9964 & 0.9677 \\
\hline & 72 & 64.0 & 113.3 & 144.0 & 285.7 & 0.5628 & 0.261 & 0.988 & 0.9841 \\
\hline
\end{tabular}

Also, tested ethanolic and hexane extracts of $L$. camara and E. citriodora (leaves) evoked a variable degree of repellency as shown in table (3). Potent repellency $(92.5 \%)$ achieved by $L$. camara hexane extract at $1.67 \mathrm{mg} / \mathrm{cm}^{2}$ through the $3 \mathrm{~h}$ post treatment, the ethanolic extracts of L. camara and E. citriodo- $r a$ exhibited $86.2,68.8,57.9$ and $74.1,59.0,47.3 \%$ protection at $3.33,1.67$ and $0.83 \mathrm{mg} / \mathrm{cm}^{2}$. Also, $E$. citriodora (leaves) hexane extract showed 88.1, 77.8 and $53.7 \%$ repellency at $3.33,1.67$ and $0.83 \mathrm{mg} /$ $\mathrm{cm}^{2}$, compared with $100.0 \%$ repellency for DEET at $1.8 \mathrm{mg} / \mathrm{cm}^{2}$ (Table 3).

Table (3) : Repellent activity of tested L. camara and E. citriodora leaves extracts against C. antennatus starved females.

\begin{tabular}{|c|c|c|c|c|c|c|c|c|}
\hline \multirow{2}{*}{ Plant Sp. } & \multirow{2}{*}{ Extract } & \multirow{2}{*}{$\begin{array}{c}\text { Dose } \\
\left(\mathrm{mg} / \mathrm{cm}^{2}\right)\end{array}$} & \multirow{2}{*}{$\begin{array}{c}\text { No. of } \\
\text { tested } \\
\text { females }\end{array}$} & \multicolumn{2}{|c|}{ Fed Females } & \multicolumn{2}{|c|}{ Unfed Females } & \multirow{2}{*}{$\begin{array}{c}\text { Repellency } \\
(\%)\end{array}$} \\
\hline & & & & No. & $\%$ & No. & $\%$ & \\
\hline \multirow{6}{*}{ L. camara } & \multirow{3}{*}{ Ethanol $70 \%$} & 3.33 & 45 & 6 & 13.3 & 39 & 86.7 & 86.2 \\
\hline & & 1.67 & 63 & 19 & 30.2 & 44 & 69.8 & 68.8 \\
\hline & & 0.83 & 59 & 24 & 40.7 & 35 & 59.3 & 57.9 \\
\hline & \multirow{3}{*}{ Hexane } & 1.67 & 55 & 4 & 7.3 & 51 & 92.7 & 92.5 \\
\hline & & 0.83 & 58 & 11 & 19.0 & 47 & 81.0 & 80.4 \\
\hline & & 0.41 & 47 & 12 & 25.5 & 35 & 74.5 & 73.6 \\
\hline \multirow{6}{*}{ E. citriodora } & \multirow{3}{*}{ Ethanol 70\% } & 3.33 & 60 & 15 & 25.0 & 45 & 75.0 & 74.1 \\
\hline & & 1.67 & 53 & 21 & 39.6 & 32 & 60.4 & 59.0 \\
\hline & & 0.83 & 49 & 25 & 51.0 & 24 & 49.0 & 47.3 \\
\hline & \multirow{3}{*}{ Hexane } & 3.33 & 61 & 7 & 11.5 & 54 & 88.5 & 88.1 \\
\hline & & 1.67 & 65 & 14 & 21.5 & 51 & 78.5 & 77.8 \\
\hline & & 0.83 & 58 & 26 & 44.8 & 32 & 55.2 & 53.7 \\
\hline DEET & $\begin{array}{ll}--- \\
--\end{array}$ & 1.8 & 49 & 0 & 0.0 & 49 & 100.0 & 100.0 \\
\hline Control & ---- & 0.0 & 61 & 59 & 96.7 & 2 & 3.3 & 0.0 \\
\hline
\end{tabular}




\section{DISCUSSION}

Earlier authors reported that the bio insecticides, particularly those are derived from plant origin, have been increasingly evaluated in controlling the population of insects' pest (Suresh et al., 2017). Crude or partially purified plant extracts are rich source of bioactive chemicals, less expensive and highly efficacious for the control of dipterans. Several studies concerning with the effect of several plant extracts on different mosquitos species were performed by many authors worldwide. Culex antennatus has been reported to be prone to infection by Rift Valley Fever virus in the Nile Delta of Egypt. In the present study, ethanol 70\% and hexane extracts of Lantana camara and Eucalyptus citriodora leaves exhibited larvicidal activity against $3^{\text {rd }}$ instar larvae of $C$. antennatus. These results were corroborate with the findings of Vahitha et al. (2002) who reported that, $\mathrm{LC}_{50}$ values of Pavonia zeylanica and Acacia ferruginea leaf extracts was 2214.7 and 5362.6 ppm against late third instar larvae of $C$. quinquefasciatus, Prabakar and jebanesan (2004) used extracts from five species of Cucurbitacious plants, Momordica charantia, Trichosanthes anguina, Luffa acutangula, Benincasa cerifera and Citrullus vulgaris against the late third larval age of $C$. quinquefasciatus. The $\mathrm{LC}_{50}$ values after $24 \mathrm{~h}$ were 465.85, 567.81, 839.81, 1189.30 and $1636.04 \mathrm{ppm}$. Similar results were reported by Nathan et al. (2005) who concluded that, azadirachtin was most potent in all experiments against the malaria vector, A. stephensi $\mathrm{L}$. and produced almost $100 \%$ larval mortality at $1 \mathrm{ppm}$ concentration, Coria et al. (2008) for extracts from Melia azedarach on $A$. aegypti. Also, Maurya et al. (2009) have reported that, the petroleum ether extract from leaves of $\mathrm{Oci}$ mum basilicum was found to be the most effective against the larvae of both mosquitoes, A. stephensi and $C$. quinquefasciatus with $\mathrm{LC}_{50}$ values of 8.29 , $4.57 ; 87.68,47.25 \mathrm{ppm}$ and $\mathrm{LC}_{90}$ values of 10.06 , $6.06 ; 129.32,65.58 \mathrm{ppm}$ against $A$. stephensi and C. quinquefasciatus after 24 and $48 \mathrm{~h}$ of treatment, Madhua et al. (2010) used Curcuma aromatica rhi- zomes extracts on C. quinquefasciatus larvae. They recorded that, the efficacy of petroleum ether extract seemed to be effective with $\mathrm{LC}_{50}$ and $\mathrm{LC}_{90}$ values of 11.4 and $18.0 \mathrm{ppm}$, this was in agreement with Sakthivadivel et al. (2014) who found that, aqueous fruit extract of Wrightia tinctoria exhibited highest larvicidal activity against the filarial vector, $C$. quinquefasciatus followed by aqueous leaf extract with $\mathrm{LC}_{50}$ values of $0.17 \%$ and $0.09 \% ; 0.21 \%$ and $0.11 \%$ after 24 and $48 \mathrm{~h}$, Samuel et al. (2014) who mentioned that, Ipomoea cairica and Ageratina adenophora extracts were found to be effective against third instar larvae of $C$. quinquefasciatus causing $77-100 \%$ mortality at $48 \mathrm{~h}$. Also, these results are in consistent with those obtained by Asiry et al. (2017) for ethanolic leaf extracts from four plants, Citrullus colocynthis, Artemisia annua, Pergularia tomentosa and Rhanterium epapposum selected from Hail region, northern Saudi Arabia, against the larval stages of Ae. aegypti. Where, the ethanolic extracts of both $R$. epapposum and $A$. апnua were more toxic to the $4^{\text {th }}$ instar larvae of Ae. aegypti compared to the other two plants and Nasir et al., (2017) used essential oils from some medicinal plants against Aedes albopictus. Where, Ginger was more effective with the lowest $\mathrm{LC}_{50}$ values after 8 and $16 \mathrm{~h}$ followed by peppermint, basil, eucalyptus and neem. In addition, basil was efficacious after 24 and $48 \mathrm{~h}$.

On the other hand, all doses of plant extracts used in the present study exhibited repellent activity against the starved female adults of $C$. antennatus. The repellent activity was varied according to solvent used in extraction and the dose of the extract. These results indicate that, the petroleum ether extraction of L. camara and E. citriodora leaves was more effective in exhibiting the repellent action against the mosquito tested as compared with ethanolic extraction. Many plant extracts and essential oils manifest repellent activity against different mosquito species and the present results are in accordance with such results obtained by Choi et al. (2002) testing the essential oils of Eulcalyptus globulus, Lavender offici- 
nalis, Rosemarinus officinalis and Thymus vulgaris against $C$. pipiens, Jeyabalan et al. (2003) using methanol extracts of Pelargonium citrosa against A. stephensi, Tuetun et al. (2004) using extracts of Apium graveolens seeds against Ae. aegypti, Yang et al. (2004) using methanol extracts from twenty three aromatic medicinal plant species against $A e$. aegypti female, Prajapati et al. (2005) using essential oils extracted from ten medicinal plants against A. stephensi and C. quinquefasciatus and Chio and Yang (2008) using neem tree (Azadirachta indica) oil against the Asian tiger mosquito (Ae. albopictus). Similar observation was also recorded by El- Sheikh et al. (2012) who used methanolic extract of Tribulus terrestris (leaves and seeds) against the malarial vector, A. arabiensis and they reported that, The seeds extract was more effective in exhibiting the repellent action (100.0\%) against the mosquito tested as compared with the leaves extract $(79.5 \%)$ at the dose 1.0 and $2.0 \mathrm{mg} / \mathrm{cm}^{2}$ compared with $(100.0 \%)$ of commercial formulation, N. N. diethyl- meta- toulamide (DEET), Adhikari and Chandra (2014) who recorded that, petroleum ether leaf extract of Swietenia mahagoni against $A$. stephensi showed repellency up to $2 \mathrm{~h}$ after treatment and Govindarajan et al. (2014) who used extracts from Delonix elata against malaria vector $A$. stephensi and they reported that, both leaf and seed methanol extracts showed maximum efficacy at the highest concentration of $5.0 \mathrm{mg} / \mathrm{cm}^{2}$ they provided over 210 and $180 \mathrm{~min}$. protection.

\section{CONCLUSION}

From the present study we conclude that, Lantana camara and Eucalyptus citriodora extracts proved promising larvicidal and repellent agents against Rift Valley Fever vector, Culex antennatus (Becker) in the laboratory. Further, in near future we need to initiate studies leading to find the bioactive compounds in L. camara and E. citriodora which may responsible for larvicidal and repellent activity.

\section{REFERENCES}

- Abbott, W.S. (1925): A method for computing the effectiveness of an insecticide. J. Econ. Entomol., 18: 265.

- Adham, F.K.; Gabre, R.M.; Ayaad, T.H. and Galal, F.H. (2003): the effect of laboratory Hepatozoom gracilis infection on the fecundity, mortality and longevity of Culex pipiens Linnaeus (Diptera: Culicidae) in Egypt. J. Egypt Soc. Parasitol., 33(2):353.

- Adhikari, U. and Chandra, G. (2014): Larvicidal, smoke toxicity, repellency and adult emergence inhibition effects of leaf extracts of Swietenia mahagoni Linnaeus against Anopheles stephensi Liston (Diptera: Culicidae). Asian Pac. J. Trop. Dis., 4(1): 279.

- Asiry, K. A.; Hassan, S. S. M.; Ibrahim, N. A.; AlKhuraiji, I. A.; Kehial, M. A.; Al-Anazi, N. A.; Alnasser, A. S. and Al-Shehri, A. Z. (2017): Larvicidal efficacy of ethanolic leaf extracts of four selected local plants from hail region, northern Saudi Arabia, against the dengue fever vector, Aedes aegypti (L.) under laboratory conditions. Int. J. Mosq. Res., 4(3): 81.

- Chio, E.H. and Yang, E.C. (2008): A bioassay for natural insect repellents. J. Asia Pac. Entomol., 11: 225.

- Choi, W.S.; Park, B.S.; Ku, S.K. and Lee, S.E. (2002): Repellent activities of essential oils and monoterpenes against $C$. pipiens pallens. J. Am. Mosq. Control. Assoc., 18(4): 348.

- Coria, C.; Almiron, W.; Valladares, G.; Carpinella, C.; Luduen a, F.; Defago, M. and Palacios, S. (2008): Larvicide and oviposition deterrent effects of fruit and leaf extracts from Melia azedarach L. on Aedes aegypti (L.) (Diptera: Culicidae). Bioresource Technol., 99: 3066.

- El- Sheikh, T.M.Y.; Bosly, H.M.A. and Shalaby, N. (2012): Insecticidal and repellent activities of methanolic extract of Tribulus terrestris L. (Zygophyllaceae) against the malarial vector Anopheles arabiensis 
(Diptera: Culicidae). Egypt. Acad. J. Biol. Sci., 5(2): 13.

- Finney, D.J. (1971): Probit analysis Third edition. Cambridge Univ. Press., 333p.

- Govindarajan, M.; Rajeswary, M. and Sivakumar, R. (2014): Repellent properties of Delonix elata (L.) Gamble (Family: Fabaceae) against malaria vector Anopheles stephensi (Liston) (Diptera: Culicidae). J. Saudi Soc. Agric. Sci., 14(2): 128

- Jeyabalan, D.; Arul, N. and Thangamathi, P. (2003): Studies on effects of Pelargonium citrosa leaf extracts on malarial vector, A. stephensi Liston. Bioresour. Technol., 89(2): 185.

- Johnson, A.D. and Singh, A. (2017): Larvicidal activity and biochemical effects of Apigenin against Filarial Vector Culex quinquefasciatus. Int. J. Life. Sci. Scienti. Res., 3(5): 1315.

- Lentner, C.; Lentner, C. and Wink, A. (1982): Studentis t- distribution tables. In Geigy scientific Tables Vol. 2. International Medical and Pharmaceutical information, Ciba- Geigy Limited, Basal, Switzerland.

- Madhu, S.K.; Shaukath, A.K. and Vijayan, V.A. (2010): Efficacy of bioactive compounds from Curcuma aromatica against mosquito larvae. Acta Trop., 113(1): 7 .

- $\quad$ Maurya, P.; Sharma, p.; Mohan, L.; Batabyal, L. and Srivastava, C.N. (2009): Evaluation of the toxicity of different phytoextracts of Ocimum basilicum against Anopheles stephensi and Culex quinquefasciatus. J. Asia Pac. Entomol., 12 (2): 113.

- Nasir, S.; Nasir, I.; Asrar, M. and Debboun, M. (2017): Larvicidal and pupicidal action of medicinal plant extracts against dengue mosquito Aedes albopictus (Skuse) (Diptera: Culicidae). Indian J. Anim. Res., 51(1): 155.

- Nathan, S.S.; Kalaivani, K. and Murugan, k. (2005): Effects of neem limonoids on the malaria vector A. stephensi Liston (Diptera: Culicidae). Acta Trop., 96(1): 47.
- $\quad$ Perveen, A.; Sarwar, G. and Hussain, I. (2008): Plant biodiversity and phytosociological attributes. Pak. J. Bot., 40 (1): 17.

- $\quad$ Prabakar, K. and Jebanesan, A. (2004): Larvicidal efficacy of some Cucurbitacious plant leaf extracts against C. quinquefasciatus (Say). Bioresour. Technol., 95(1):113.

- $\quad$ Prajapati, V.; Tripathi, A.K.; Aggarwal, K.K. and Khanuja, S.P. (2005): Insecticidal, repellent and oviposition-deterrent activity of selected essential oils against A. stephensi, Ae. aegypti and C. quinquefasciatus. Bioresour. Technol., 96(16): 1749.

- Raharimalala, F. N.; Ravaomanarivo, L. H.; Ravelonandro, P.; Rafarasoa, L. S.; Zouache, K.; Tran-Van, V.; Mousson, L.; Failloux, A.; Hellard, E.; Moro, C. V.; Ralisoa, B. O. and Mavingui, P. (2012): Biogeography of the two major arbovirus mosquito vectors, Aedes aegypti and Aedes albopictus (Diptera, Culicidae), in Madagascar. Parasit Vectors, 5: 56.

- Ravaomanarivo, L.H.R.H.; Razafindraleva, A.; Raharimalala, F.N.; Rasoahantaveloniaina, B. Ravelonandro, P.H. and Mavingui, P. (2014): Efficacy of seed extracts of Annona squamosa and Annona muricata (Annonaceae) for the control of Aedes albopictus and Culex quinquefasciatus (Culicidae). Asian Pac J Trop Biomed., 4(10): 798.

- Sakthivadivel, M.; Gunasekaran, P.; Annapoorani, J.T.; Samraj, D.A.; Arivoli, S. and Tennyson, S. (2014): Larvicidal activity of Wrightia tinctoria R. BR. (Apocynaceae) fruit and leaf extracts against the filarial vector Culex quinquefasciatus Say (Diptera: Culicidae). Asian Pac. J. Trop. Dis., 4(1): 373.

- Samuel, L.; Lalrotluanga; Muthukumaran, R.B.; Gurusubramanian, G. and Senthilkumar, N. (2014): Larvicidal activity of Ipomoea cairica (L.) Sweet and Ageratina adenophora (Spreng.) King \& H. Rob. plant extracts against arboviral and filarial vector, $\mathrm{Cu}$ lex quinquefasciatus Say (Diptera: Culicidae). Exp. Parasitol., 141: 112. 
- Su, T. and Mulla, M.S. (1998): Antifeedancy of neem products containing Azadirachtin against $C$. tarsalis and C. quinquefasciatus (Diptera: Culicidae). J. Vector. Ecol., 23(2): 114.

- Suresh, M.; Premraj, L. and Kalaiarasi, J.M.V. (2017): Bioefficacy and larvicidal activity of Couroupita guianensis (Aubl) against housefly, Musca domestica (L). J. Entomol. Zool. Stud., 5(5): 429.

- Thomas, C. J. and Callaghan, A. (1999): The use of garlic (Allium sativa) and lemon peel (Citrus limom) extracts as Culex pipiens larvacides: Persistence and interaction with an organophosphate resistance mechanism. Chemosphere., 39: 2489.

- Tuetun, B.; Choochote, W.; Rattanachanpichai, E.; Chaithong, U.; Jitpakdi, A.; Tippawangkosol, P.; Riyong, D. and Pitasawat, B. (2004): Mosquito repellency of the seeds of celery (Apium graveolens L.). Ann. Trop. Med. Parasitol., 98(4): 407.

- Vahitha, R.; Venkatachalam, M.R.; Murugan, K. and Jebanesan, A. (2002): Larvicidal efficacy of Pavonia zeylanica L. and Acacia ferruginea D.C. against $C$. quinquefasciatus Say. Bioresour. Technol., 82(2): 203.
- Williams, K.A.; Green, D.W.J.; Pascoe, D. and Gower, D.E. (1986): The acute toxicity of cadmium to different larval stages of Chrionomus riparius (Diptera: Chironomidae) and its ecological significance for pollution regulation. J. Sci. Unvi. Tokushima. 22: 25 .

- Yang, Y.C.; Lee, E.H.; Lee, H.S.; Lee, D.K. and Ahn, Y.G. (2004): Repellency of aromatic medicinal plant extracts and a steam distillate to Ae. aegypti. J. Am. Mosq. Control. Assoc. 20(2): 146.

- Yang, Y.C.; Lee, S.G.; Lee, H.K.; Kim, M.K.; Lee, S.H. and Lee, H.S. (2002): A piperidine amid extracted from Piper longum L. fruit shows activity against Ae. aegypti mosquito larvae. J. Agric. Food. Chem., 50(13): 3765. 
